\title{
紀伊半島の中央構造線付近に見られる 深部流体と地質・地質構造
}

\author{
田中 和広 $* 1 \cdot$ 東田 優記 $* 2 \cdot$ 村上 裕晃 $* 3$
Deep-seated fluid around the Median Tectonic Line, Kii Peninsula and its relationship to geologic structure

Kazuhiro TANAKA*1, Yuki HIGASHIDA*2 and Hiroaki MURAKAMI*3

\begin{abstract}
Through a geological survey, this study examines the geochemical properties of groundwater and river water distributed in the environs of the Median Tectonic Line (MTL) on Kii Peninsula, Japan, and their upwelling paths in the upper crust. Carbon dioxide-bearing water spouting in the environs of the MTL is assumed to be contaminated by Arima-type fluid derived from the subducted Philippine Sea slab, based on the result of water quality, oxygen-hydrogen isotope ratio, and helium isotope ratio. Arima-type fluid is presumed to ascend along the MTL fracture zones and related faults parallel to the MTL. NaCl-type and $\mathrm{Ca}\left(\mathrm{HCO}_{3}\right)_{2}$-type groundwaters with high concentrations of $\mathrm{Cl}^{-}$discharge in the northern part of the study area at the related faults, and $\mathrm{CaSO}_{4}$-type and $\mathrm{Ca}\left(\mathrm{HCO}_{3}\right)_{2}$-type groundwaters including some high concentrations of $\mathrm{Cl}^{-}$spout out on the MTL in the southern part of the study area. Arima-type fluid is diluted by the local groundwater system and erupts at the intersection of faults and rivers. Cataclasites and microfractures accompanied in the faults are filled with calcite veins, showing that the fluid penetrates into them, where calcite then precipitates. As a result, the discharge path to the ground surface is sealed and eruption points then migrate to fresh fractures.
\end{abstract}

Key words: Median Tectonic Line, highly saline groundwater, geologic structure, slab-derived fluid

I 、はじめに

近年，地下深部の利用開発計画，建設が進めら れている。重要な地下構造物の立地選定や安全性 の評価においては構造物の力学的安定性に加え, 深部地下水の地化学的特性や地下水流動特性に関 する評価が求められている。

地下深部には天水や海水を起源とする地下水が 分布しており, イオンの溶出, イオン置換, 酸化
還元反応により水質が形成されることなどが明 らかとなっている（核燃料サイクル開発機構, 1999）。一般に深部岩盤は透水性が低く，動水勾 配が小さいことから地下水の流動速度は極めて遅 く，放射性核種の移行を遅延させる還元的環境で あることが明らかとなりつつある。

一方， $300 \mathrm{~m}$ 以深に分布する深部地下水には, スラブ起源とされる高塩濃度地下水 (深部流体), 地熱流体, 背弧側の堆積岩分布地域に分布する高

* 1 山口大学理工学研究科 Graduate School of Science and Engineering, Yamaguchi University

* 2 (株) ニュージェック NEWJEC Inc.

*3 日本原子力研究開発機構 Japan Atomic Energy Agency (JAEA) 
田中・東田 $\cdot$ 村上

塩濃度深部地下水などがあり，それらは，様々な 地質変動により地表付近に上昇, 涌出することが 知られている (産業技術総合研究所深部地質環境 研究センター，2007）。

火山フロントより前弧側の非火山性地域には中 央構造線（以下MTLと呼ぶ）などの断裂系に 沿って高塩濃度地下水の湧出が知られて打り (Umeda et al., 2006), 希ガスの同位体比などよ り，これらはスラブ起源の深部流体とされ（産業 技術総合研究所深部地質環境研究センター, 2007), 有馬型熱水と呼ばれている（松葉谷ほか, 1974）。有馬型熱水は，天水起源の地下水とは異 なり, 深部から上昇すること, $\mathrm{Cl}^{-}$や $\mathrm{CO}_{2}$ を多量 に含み反応性に富むことなどから，深部地下水環 境に大きな影響を与えると考えられる。そのため， 安定な地下水環境が期待される高レベル放射性廃 棄物の地層処分においては地下施設のサイト選定 や地下水環境の長期安全性評価を行う際, 有馬型 熱水の影響の有無は重要な調査・評価項目の一つ となっている(産業技術総合研究所深部地質環境 研究センター, 2007)。特に, 有馬型熱水が上昇 する場を一般化することは，上記地下施設のサイ 卜選定に打いて重要な検討課題と考えられる。

紀伊半島には, 高塩濃度地下水の湧出が知られ て抢り，水質と同位体分析の結果より，調査地域 北部の地下水は有馬型熱水と天水の混合と考えら れている。また，ガスのヘリウム同位体比 $\left({ }^{3} \mathrm{He} /{ }^{4} \mathrm{He}\right)$ は $2.1 \sim 6.1 \mathrm{R}_{\mathrm{A}}\left(\mathrm{R}_{\mathrm{A}}\right.$ : 大気成分で規格 化した值）を示し（東田・田中，2009），1.0 $\mathrm{R}_{\mathrm{A}}$ よりも大きいことからマントル起源のへリウムが 卓越していると考えられる (Matsumoto et al., 2003)。

既に我が国の主要な構造線に沿って，スラブ起 源の深部流体が存在することや, 地下深部におけ る流体の上昇・移動に関する研究がなされている (風早ほか，印刷中)。しかし，上部地殼における 流体の移動経路や地表における湧出地点と地質構 造との関連性に関する議論は進んでいない。本研 究では, 紀伊半島内陸部に打ける有馬型熱水の上 昇過程や流動形態との関係について，主に，地表
部における構造地質学調査と地下水の地化学調査 の結果から考察を行い, 有馬型熱水の涌出する場 を規制する要因を検討することを目的とする。

\section{II. 調査地域の概要}

\section{1. 地形および地域概要}

調査地域は, 大阪府南東部の河内長野市から和 歌山県北東部の橋本市にかけての地域である (Fig. 1)。周辺には，標高 $700 〜 800 \mathrm{~m}$ の峰々か らなる和泉山脈が連なる。

調査地域北部を流れる石川や加賀田川，天見川 などの河川は大和川水系であり, 和泉山脈から北 に向かって流下している。一方，調査地域南部に は, 一級河川である紀の川が東から西に向かって 流下しており, 紀の川の支流である橋本川や山田 川, 田原川などの河川は和泉山脈から南に向かっ て流下している。

\section{2. 地質概要}

Fig. 1に調查地域周辺の地質図（水野ほか, 1994 ; 産業技術総合研究所地質調查総合セン ター，2010）に流体の涌出地点（Loc.）および 試料番号（no.）を示す。中沢ほか（1987）によ ると，MTLより北側は西南日本内帯にあたり， 白亜紀の領家帯花崗岩類と泉南流紋岩類を基盤と し，その南側には上部白亜系和泉層群が東西に延 びて分布している。北部には領家帯花崗岩類を不 整合に覆う鮮新〜更新世の大阪層群, 段丘堆積物 および完新統が分布する。

一方, MTLの南側は西南日本外帯にあたり, 三波川結晶片岩類を基盤とし, これを覆って鮮 新〜更新世の菖蒲谷層, 段丘堆積物, 扇状地堆積 物および完新統が分布する (Fig. 1)。

小林（1951）によると, MTLの運動時期は鹿 塩時階 (白亜紀), 市の川時階 (漸新〜中新世), 砥部時階（鮮新世）および菖蒲谷時階（更新世） の 4 時階に分けられる。狭義のMTLである和泉 層群と三波川結晶片岩類との境界をなす地質上の 大きな構造線は市の川時階に活動した断層とされ 

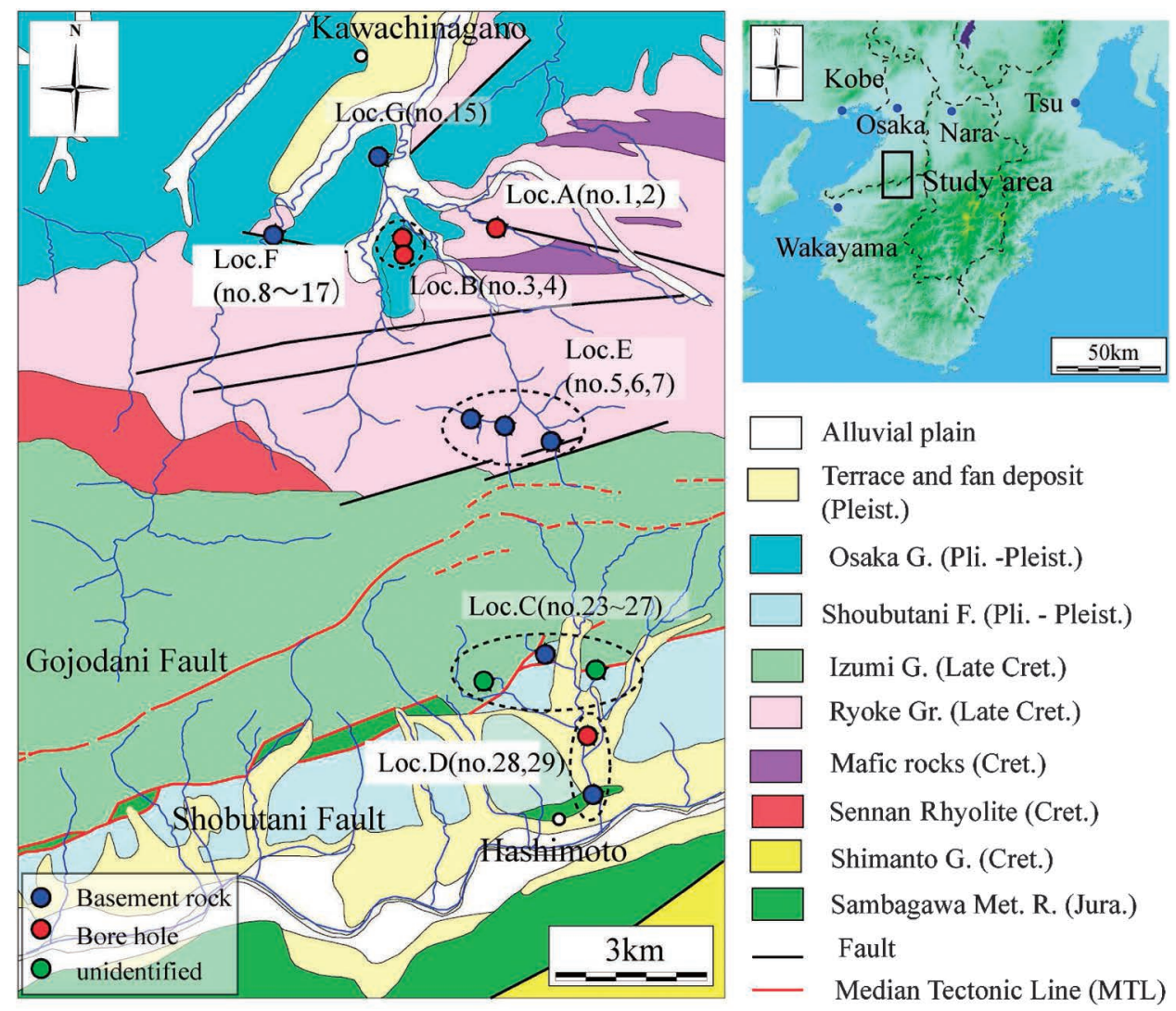

Fig. 1 Maps of the study area, showing its location, geology, groundwater discharge points (Loc.) and sample number (no.). Compiled from Mizuno et al. (1994) and AIST (2010). Fluid spouts from basement rocks (blue circle), boreholes (red circle), and unidentified points (green circle).

ている。また，MTLの新期の活動は北方に分布 する根来断層, 五条谷断層打よび金剛断層に移行 しており，中央構造線活断層系を構成している (岡田・寒川，1978)。調査地域に分布するMTL は，地質境界としてのMTLと菖蒲谷時階の菖蒲 谷断層，後期更新世〜完新世にかけて活動的とさ れる五条谷断層からなり（寒川・岡田，1977）， およそENE-WSW方向に並列して分布してい る。また, 調査地域北部には, MTLに平行して NE-SW P EW方向の断層が分布している。

\section{III. 地下水の湧出箇所と地質構造}

\section{1. 地下水の湧出箇所の一般的特徵}

調査地域には三波川結晶片岩類や和泉層群, 領
家帯花崗岩類が分布する箇所で岩盤から地下水が 直接湧出している。また, $\mathrm{CO}_{2}$ ガスを採取するた めのボーリング孔 (Fig. 1; Loc. A, B) からも地 下水が湧出している。このような地下水の湧出は 大部分が河床や谷底に限られる。

地下水の湧出箇所周辺には, MTL活断層系に 属する菖蒲谷断層や北部のMTLに平行な断層群 が推定されている（水野ほか，1994）。ここで は, 大阪府河内長野市南西部の石川河床部 (Fig. 1; Loc. F）における地下水やガスの涌出の状況と 地質・地質構造について述べる。

2. MTL北方, 河内長野市汐滝橋露頭 (Loc. F) に見られる湧水

MTL 北方の大阪府河内長野市南西部を流れる 
石川の汐滝橋上流の河床部において，上下流 $150 \mathrm{~m}$ 区間に分布する片状組織を呈する領家帯古 期花崗岩類に発達する割れ目から, 方解石や赤褐 色沈殿物を伴う地下水の湧出や二酸化炭素ガスの 噴出が認められる。

Fig. 2 に露頭の地質・地質構造と地下水・ガス の湧出箇所を示す。露頭は全体に著しく割れ目が 発達し, 特に, 北部には幅数 $10 \mathrm{~cm}$ の破砕帯を伴 う断層が 2 条認められ( $\mathrm{f}-1, \mathrm{f}-2)$ ，それぞれ幅 $1 \sim 2 \mathrm{~m}$ の破砕の著しいカタクレーサイトを伴 う。断層の方向がそれぞれ $\mathrm{N} 40^{\circ} \mathrm{W} / 54^{\circ} \mathrm{N}, \mathrm{N} 40^{\circ} \mathrm{E} /$ $50^{\circ} \mathrm{N}$ であることや，カタクレーサイトの連続性 などの検討結果により，これらはMTLの北方に 推定されている東西方向の断層群（水野ほか, 1994）と同様の成因をもつ断層と考えられる (以下 RFと呼ぶ)。

地下水の湧出箇所は露頭全域に認められるが,
主な湧水地点は北部に片寄っており, 中央部，南 部ではスポット状に分布する。ガスの噴出箇所 は，北部〜中央部にのみ認められ，スポット状に 分布する。地下水，ガスの湧出箇所の分布配列は その場所における卓越する割れ目の方向と良い相 関が認められる。

露頭観察の結果, 白いにじみとして方解石が岩 盤を覆っている箇所や割れ目やカタクレーサイト の基質部を方解石が充填している箇所が認められ る (Fig. 3)。さらに, 方解石の沈殿物である トゥファ（狩野，1997）も認められる。方解石 の沈殿や充填は有馬型熱水の湧出の際に $\mathrm{CO}_{2}$ カ スの脱ガスによる $\mathrm{CO}_{2}$ 分圧の低下が原因と考え られ，方解石の充填は過去に有馬型熱水が浸透 し，割れ目間隙中を流動した痕跡と考えられる。 河床部の岩盤上には方解石が数 $\mathrm{cm}$ の円錐状の石 简状沈殿物からなる小さな高まり (calcite cone)

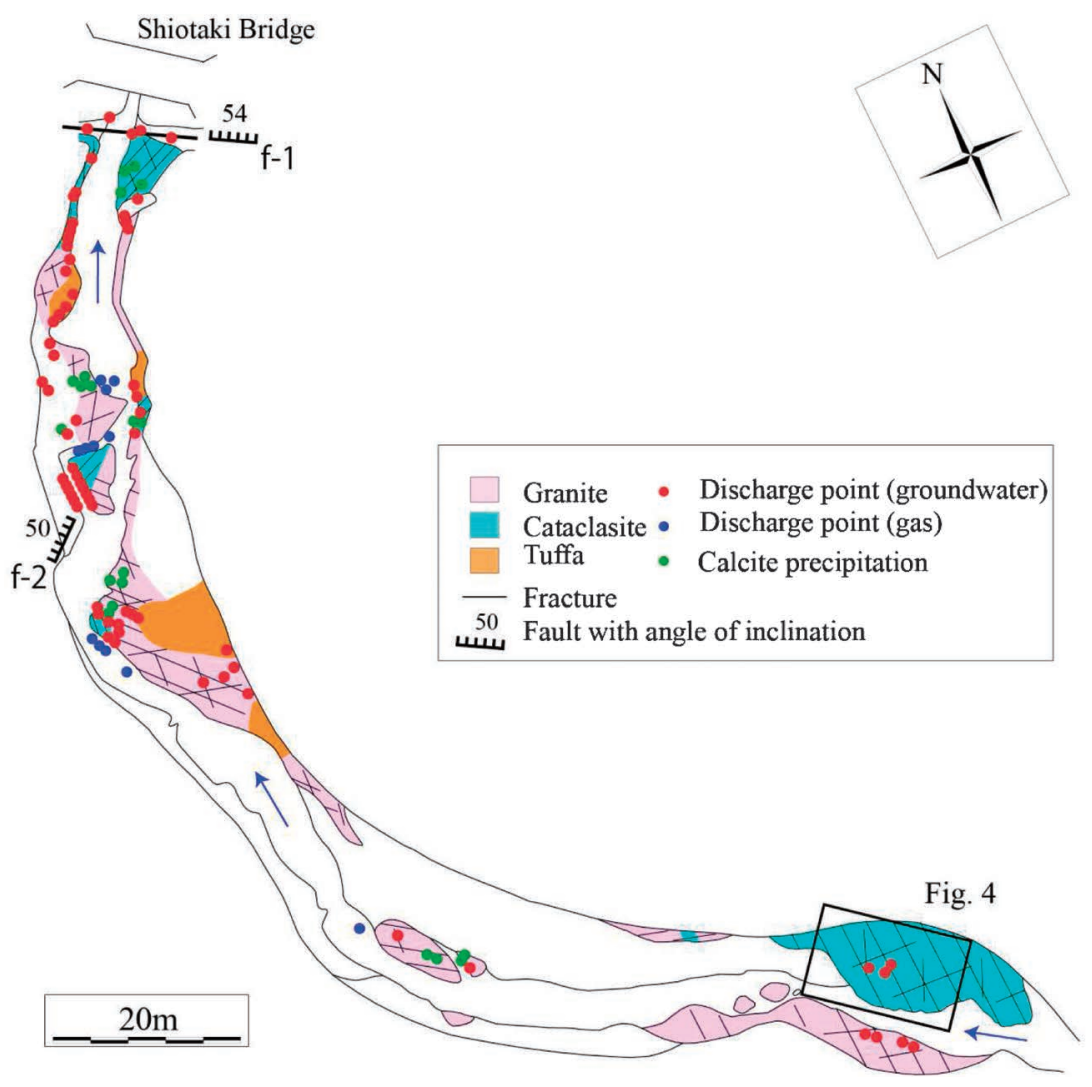

Fig. 2 Sketch of the outcrop at Loc. F. Blue arrow shows the river flow direction. 
(a)

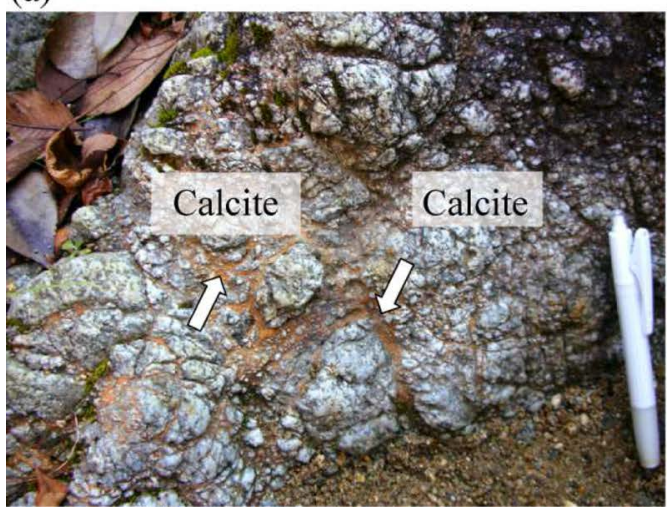

(b)

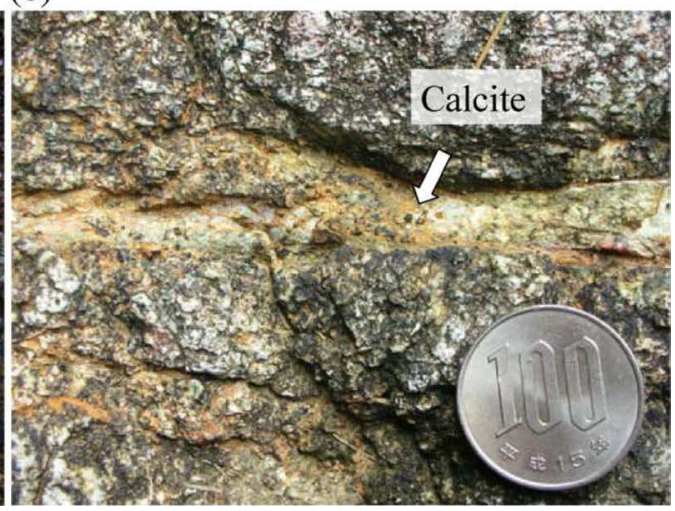

Fig. 3 Photographs of outcrop at Loc. F. Matrix of cataclasite (a) and fractures (b) are filled with calcite veins.

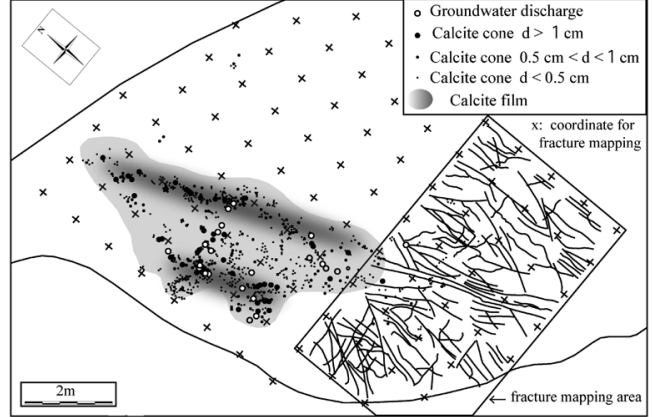

Fig. 4 Distribution of stalagmite-shaped precipitation (calcite cone), groundwater discharge points, and fractures in the southern part of Loc. F, shown in Fig. 2. Fracture mapping area is indicated by a square.

\section{を形成している。}

露頭に発達する割れ目の方向と石简状沈殿物や 地下水の湧出箇所との関係について検討を行うた め, 露頭南部の Fig. 4の枠内に打いて詳細な割れ 目のマッピング，卓越方向の検討を行った。抽出 した割れ目の総数は 123 本である。卓越する割れ 目は, $\mathrm{NS}$ 走向 /中角〜高角傾斜及び $\mathrm{N} 50^{\circ} \mathrm{W}$ 走 向 /中角傾斜に卓越方向を持つ 2 グループに区分 することができ，特にNS方向の割れ目が卓越 している (Fig. 5)。方解石の沈殿物は全体的に $\mathrm{NS} \sim \mathrm{NNW-SSE}$ 方向に配列し，涌水を伴う石 简状沈殿物 (calcite cone) にはNS方向と EW方 向の配列が認められることから, 卓越した割れ目

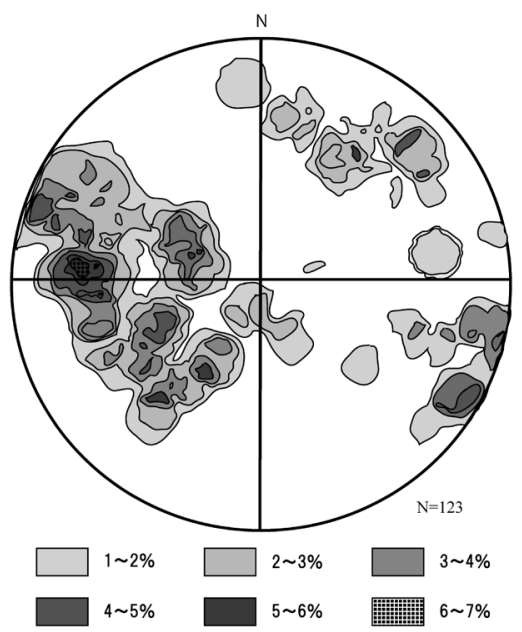

Fig. 5 Schmidt stereonet plots (lower hemisphere) of fractures measured in the fracture mapping area shown in Fig. 4.

沿いに流体が滃出しているものと考えられる。

カタクレーサイトは鏡下観察の結果, 全体に鉱 物単位で破砕が進んでおり (Fig. 6), 割れ目沿 いには幅 $0.5 \mathrm{~mm}$ の微角礫を含む脈状の構造が認 められる (Fig. 6; (1) A and (2) B)。微角碟の 構成鉱物は，石英，斜長石，黒雲母打よび方解石 であり，基質部には水酸化鉄の沈殿が見られる。 微角碟の外縁は明瞭で, 微角碟と微角砂の間は方 解石もしくは不透明鉱物が充填しており，不透明 鉱物中には微小な方解石結晶を伴う。微角砂を含 む脈状構造の境界面に沿って $0.1 〜 0.3 \mathrm{~mm}$ の層 
(1)

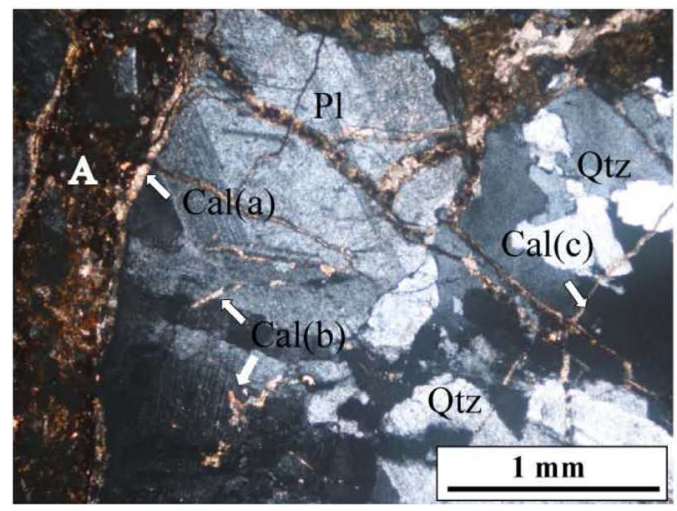

(2)

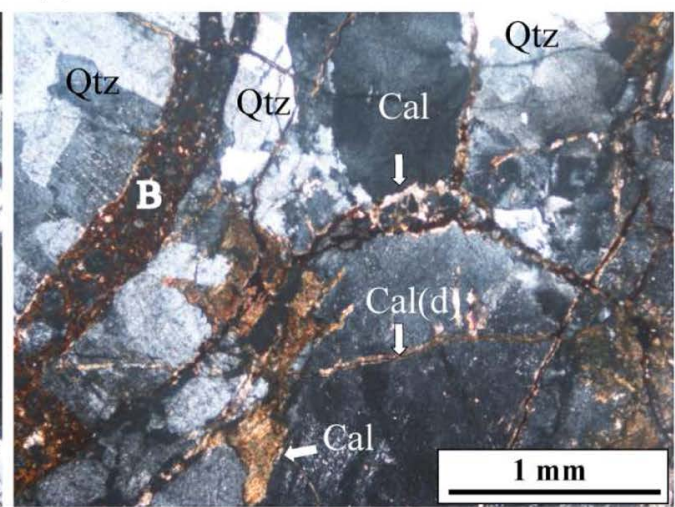

Fig. 6 Photomicrographs of cataclasite (cross-polarized light). Cataclasite is composed of fragments of quartz, feldspar, biotite, and calcite. The matrix is composed of calcite and hydrated iron. Fractures $0.5 \mathrm{~mm}$ wide (A and B) are composed of microfragments of quartz, feldspar, biotite, and calcite with sizes from 0.1 to $0.3 \mathrm{~mm}$. In photograph (1), the boundary between fracture A and its surrounding fragments is filled with calcite veins, shown as Cal (a). Microfractures are filled with calcite veins, shown as Cal (b), (c) in photograph (1), and Cal (d) in photograph (2).

状の方解石結晶が認められることから（Fig. 6; (1) Cal (a))，破砕により形成された割れ目をそ の後の深部流体の活動により方解石が充填したこ とを示唆している。

さらに，割れ目の発達する岩盤には微小変形構 造（金折ほか, 1988）が認められ，微小割れ目 が複雑に結合し，網目状を呈しており，大部分の 割れ目を方解石もしくは不透明鉱物が充填してい る (Fig. 6; (1) Cal (b), Cal (c); (2) Cal (d))。 このことから, 有馬型熱水が微小割れ目にも浸透 した可能性が示唆される。

方解石により充填された割れ目付近では，現在 は地下水の涌出や滲み出し等は確認されない。

\section{$\mathrm{N}$. 地下水 ・河川水の地化学特性}

調査地域に湧出する地下水, 河川水の水質を明 らかにするため, $\mathrm{pH}$, 電気伝導度（以下 $\mathrm{EC}$ と 省略する)，一般水質分析および酸素水素同位体 分析を行った。試料採取地点および試料番号を Table 1, Fig. 1に示す。なお，1地点（Loc.）で 複数の試料を採取した場合は, まとめて記述し た。Table 1 において灰色に塗色したデータは採
取地点において溶存イオン量が多い試料をその地 点の代表として，へキサダイアグラムを Fig. 7 に 示した。河川水の試料はFig. 7 において採取地点 にヘキサダイアグラムを示した。

\section{1. 調査手法}

一般水質 : 陽イオンは $\mathrm{Na}^{+}, \mathrm{K}^{+}, \mathrm{Ca}^{2+}, \mathrm{Mg}^{2+}$ の 4 成分を山口県産業技術センターのICP発光分 光分析装置 (Varian Technologies Japan Limited 社製VISTA-PRO）により，陰イオンは $\mathrm{Cl}^{-}$, $\mathrm{SO}_{4}{ }^{2-}$ の 2 成分を同センターのイオンクロマトグ ラフィー（日本分光社製イオンクロマトグラフ） により, $\mathrm{HCO}_{3}{ }^{-}$はアルカリ度測定により分析し た。

$\mathrm{pH}, \mathrm{EC}$ ：現地での測定は， $\mathrm{pH}$ は簡易 $\mathrm{pH}$ 計（新 電元工業社製ISFET pH METER KS701）を, EC は簡易 EC 計（堀場製作所社製 Compact Conductivity Meter) を用いて行った。採水した試 料を室内へ持ち帰った後, $\mathrm{pH}$ は東亜 DKK 社製 pH Meter HM-25Gを，ECは東亜DKK社製 EC Meter CM-30Gを用いてそれぞれ測定を行った。

酸素水素同位体: 調査地域に涌出する地下水の起 源を明らかにするため, 地下水, 河川水, 井戸水 
Table 1 Geochemical data on groundwater in the study area. Water samples listed in the gray rows are plotted as the hexa-diagrams in Fig. 7.

\begin{tabular}{|c|c|c|c|c|c|c|c|c|c|c|c|c|c|c|c|}
\hline No. & City & Loc. & Discharge & Date & $\mathrm{pH}$ & EC & $\delta^{18} \mathrm{O}$ & $\delta \mathrm{D}$ & $\mathrm{Na}$ & $\mathrm{K}$ & $\mathrm{Ca}$ & $\mathrm{Mg}$ & $\mathrm{Cl}$ & $\mathrm{HCO}_{3}$ & $\mathrm{SO}_{4}$ \\
\hline & & & & & & $\mathrm{mS} / \mathrm{m}$ & \multicolumn{2}{|c|}{$\% o$} & \multicolumn{7}{|c|}{$\mathrm{mg} / \mathrm{l}$} \\
\hline 1 & Kawachinagano & A & Spring & $2008 / 3 / 28$ & 6.6 & 2120 & -8.3 & -57 & 171.3 & 4.1 & 208.3 & 23.5 & 59.3 & 0.0 & 5.3 \\
\hline 2 & Kawachinagano & $\mathrm{A}$ & Spring & $2008 / 3 / 28$ & 6.6 & 2130 & -7.3 & -53 & 1449.7 & 9.3 & 199.7 & 112.0 & 1239.5 & 4368.9 & 0.0 \\
\hline 3 & Kawachinagano & B & Spring & $2008 / 5 / 16$ & - & - & - & - & 1623.7 & 2.9 & 326.4 & 82.7 & 1467.3 & 3197.7 & 0.0 \\
\hline 4 & Kawachinagano & $\mathrm{B}$ & Spring & $2008 / 5 / 16$ & - & - & - & - & 1854.4 & 5.1 & 489.3 & 97.6 & 1625.0 & 4112.6 & 0.0 \\
\hline 5 & Kawachinagano & $E$ & Spring & $2009 / 11 / 26$ & 6.5 & 1026 & -7.0 & -51 & 1684.4 & 15.3 & 205.0 & 75.8 & 3628.8 & 1523.0 & 3.7 \\
\hline 6 & Kawachinagano & $E$ & Spring & $2009 / 11 / 26$ & 7.7 & 257 & -7.3 & -49 & 340.7 & 4.3 & 133.1 & 58.0 & 822.7 & 380.8 & 12.9 \\
\hline 7 & Kawachinagano & $\mathrm{E}$ & Spring & $2009 / 11 / 28$ & 6.2 & 349 & -7.5 & -51 & 447.6 & 5.7 & 271.0 & 73.2 & 675.6 & 1347.3 & 5.4 \\
\hline 8 & Kawachinagano & $\mathrm{F}$ & Spring & $2008 / 3 / 27$ & 6.4 & 718 & -6.3 & -51 & 2973.3 & 75.9 & 354.2 & 120.1 & 2577.4 & 1625.5 & 20.5 \\
\hline 9 & Kawachinagano & $\mathrm{F}$ & Spring & $2008 / 3 / 27$ & 6.9 & 2270 & -8.2 & -55 & 4630.3 & 137.6 & 579.0 & 186.5 & 3493.1 & 2201.5 & 0.0 \\
\hline 10 & Kawachinagano & $\mathrm{F}$ & Spring & $2008 / 3 / 27$ & 6.8 & 2290 & -6.9 & -55 & 36.2 & 0.9 & 103.7 & 6.3 & 11.2 & 331.9 & 5.7 \\
\hline 11 & Kawachinagano & $\mathrm{F}$ & Spring & $2008 / 3 / 27$ & 6.8 & 2310 & -6.7 & -52 & 4977.9 & 54.5 & 268.1 & 96.5 & 3116.7 & 1952.6 & 0.0 \\
\hline 12 & Kawachinagano & $\mathrm{F}$ & Spring & $2008 / 3 / 28$ & 6.0 & 990 & -7.4 & -57 & 1664.4 & 49.7 & 111.4 & 30.5 & 1186.7 & 546.7 & 9.5 \\
\hline 13 & Kawachinagano & $\mathrm{F}$ & Spring & $2008 / 3 / 28$ & 6.8 & 2060 & -8.3 & -57 & 951.2 & 22.7 & 134.1 & 30.6 & 1064.8 & 1337.5 & 5.8 \\
\hline 14 & Kawachinagano & $\mathrm{F}$ & Spring & $2009 / 1 / 17$ & 6.7 & 1924 & -5.4 & -48 & 4761.8 & 168.1 & 348.5 & 277.9 & 6335.8 & 4451.4 & 0.0 \\
\hline 15 & Kawachinagano & $\mathrm{F}$ & Spring & $2009 / 1 / 17$ & 6.6 & 601 & -6.8 & -47 & 1286.2 & 53.3 & 229.0 & 72.8 & 1489.2 & 1996.4 & 0.0 \\
\hline 16 & Kawachinagano & $\mathrm{F}$ & Spring & $2009 / 1 / 18$ & - & - & -4.0 & -46 & 7315.6 & 144.4 & 523.7 & 507.6 & 10645.2 & 5461.7 & 0.0 \\
\hline 17 & Kawachinagano & $\mathrm{F}$ & Spring & $2009 / 1 / 18$ & - & - & - & - & 7433.7 & 138.4 & 267.6 & 511.5 & 10741.0 & 4841.2 & 0.0 \\
\hline 18 & Kawachinagano & G & Spring & $2009 / 9 / 18$ & 6.3 & 1057 & -5.8 & -47 & 2063.3 & 29.2 & 284.1 & 131.3 & 6570.5 & 61.0 & 8.6 \\
\hline 19 & Kawachinagano & & River & $2009 / 9 / 22$ & 7.1 & 21 & -8.0 & -52 & 21.7 & 0.6 & 24.0 & 2.7 & 57.0 & 35.8 & 9.1 \\
\hline 20 & Kawachinagano & & River & $2009 / 9 / 19$ & 7.3 & 103 & -7.5 & -51 & 129.1 & 2.0 & 77.7 & 16.5 & 314.6 & 100.3 & 18.4 \\
\hline 21 & Kawachinagano & & River & $2011 / 1 / 17$ & 7.0 & 24 & - & - & 28.5 & 2.3 & 33.2 & 4.0 & 40.7 & 78.1 & 12.2 \\
\hline 22 & Kawachinagano & & River & $2011 / 1 / 17$ & 7.4 & 50 & - & - & 73.8 & 3.5 & 42.7 & 8.0 & 138.4 & 112.3 & 12.5 \\
\hline 23 & Hashimoto & $\mathrm{C}$ & Spring & $2009 / 11 / 24$ & 7.1 & 47 & -8.4 & -55 & 34.5 & 0.5 & 75.3 & 12.8 & 5.5 & 194.6 & 143.0 \\
\hline 24 & Hashimoto & $\mathrm{C}$ & Spring & $2009 / 11 / 27$ & 6.3 & 65 & -8.1 & -53 & 38.6 & 0.7 & 74.3 & 32.1 & 11.4 & 92.7 & 225.8 \\
\hline 25 & Hashimoto & $\mathrm{C}$ & Spring & $2009 / 11 / 27$ & 6.5 & 106 & -8.2 & -52 & 70.7 & 0.9 & 167.4 & 57.3 & 10.7 & 244.1 & 391.5 \\
\hline 26 & Hashimoto & $\mathrm{C}$ & Spring & $2009 / 11 / 27$ & 8.5 & 23 & -8.0 & -55 & 18.4 & 0.3 & 36.5 & 8.4 & 4.8 & 73.2 & 69.1 \\
\hline 27 & Hashimoto & $\mathrm{C}$ & Spring & $2009 / 11 / 27$ & 7.7 & 42 & -8.4 & -56 & 25.9 & 0.5 & 48.0 & 22.7 & 1.8 & 146.4 & 107.5 \\
\hline 28 & Hashimoto & $\mathrm{D}$ & Spring & $2009 / 9 / 21$ & 8.3 & 29 & -7.6 & -51 & 19.3 & 1.1 & 34.9 & 5.6 & 25.7 & 87.8 & 43.6 \\
\hline 29 & Hashimoto & $\mathrm{D}$ & Spring & $2009 / 9 / 21$ & 6.9 & 250 & -8.1 & -56 & 104.9 & 0.9 & 108.7 & 21.6 & 186.4 & 391.7 & 5.4 \\
\hline 30 & Hashimoto & & River & $2009 / 9 / 21$ & 7.2 & 27 & -7.9 & -52 & 18.2 & 0.7 & 34.8 & 4.9 & 24.5 & 104.5 & 26.5 \\
\hline 31 & Hashimoto & & River & $2009 / 9 / 17$ & 7.3 & 19 & -7.4 & -50 & 9.0 & 0.5 & 25.5 & 2.9 & 8.9 & 72.7 & 22.9 \\
\hline 32 & Hashimoto & & River & $2009 / 9 / 21$ & 7.2 & 63 & -7.5 & -51 & 23.8 & 0.9 & 106.8 & 16.9 & 17.9 & 197.1 & 194.2 \\
\hline
\end{tabular}

の酸素水素同位体分析を行なった。

水素同位体はクロミウム還元法，酸素同位体は 同位体平衡法を前処理とする質量分析法により測 定を行った。分析は, 熊本大学嶋田研究室の質量 分析装置 (Thermo Fisher Scientific 社製Delta S）を用いた。

\section{2. 測定結果}

一般水質，酸素水素同位体の測定結果をTable 1 に示す。ECおよび $\mathrm{pH}$ は室内で計測した結果を 示す。

\section{1 一般水質}

ヘキサダイアグラムで比較すると，調査地域北 部の地下水は, 南部の地下水に比べ 2 桁ほど全溶 存イオン量が多い（Fig. 7)。また，北部の地下 水は $\mathrm{Na}^{+}, \mathrm{Cl}^{-}$および $\mathrm{HCO}_{3}{ }^{-}$に富んでおり，南部 の地下水は $\mathrm{Ca}^{2+}$ p $\mathrm{SO}_{4}{ }^{2-}$ に富んでいる。トリリ
ニアダイアグラムにおいて, 北部の地下水試料 は，ほとんどが $\mathrm{NaCl}$ 型および $\mathrm{Ca}\left(\mathrm{HCO}_{3}\right)_{2}$ 型に プロットされるのに対し，南部の地下水試料 は $\mathrm{CaSO}_{4}$ 型と $\mathrm{Ca}\left(\mathrm{HCO}_{3}\right)_{2}$ 型にプロットされる (Fig. 8, 山本, 1983)。一方, Loc. Dのボーリン

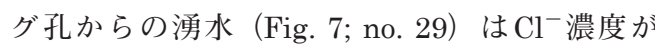
$186.4 \mathrm{mg} / \mathrm{l}$ であり, 周辺の湧水の $\mathrm{Cl}^{-}$濃度と比較 して高い值を示す。

河川水の多くは河川に一般的な $\mathrm{Ca}\left(\mathrm{HCO}_{3}\right)_{2}$ 型 を示すが, 河内長野市天見川上流の天見駅近傍 (Fig. 7; no. 20） や下流の長野温泉近傍（Fig. 7; no. 22）の河川水は $\mathrm{NaCl}$ 型地下水の湧出の影響 を受け， $\mathrm{NaCl}$ 型を示している。

\section{2 河川水の $\mathrm{EC}$}

河川水の 60 ～80\%は，地下水の流入が占める といわれており（辻村・田中，1996）, 河川水の $\mathrm{EC}$ を測定することで周囲の岩盤から河川に流出 


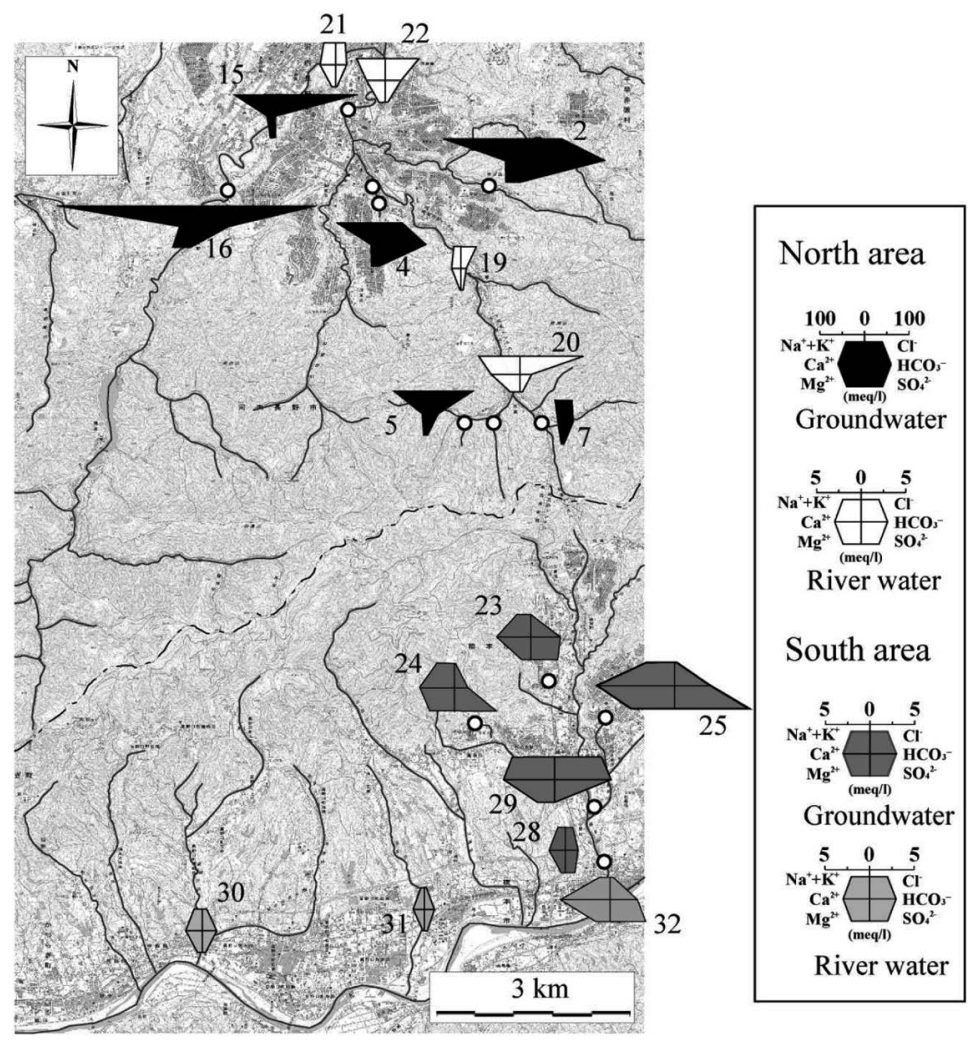

Fig. 7 Hexadiagram showing the quality of groundwater and river water. The hexadiagram of the water sample with the highest concentration of dissolved ions at the location is plotted as a representative example. Numbers correspond to the water sample numbers shown in Table 1.

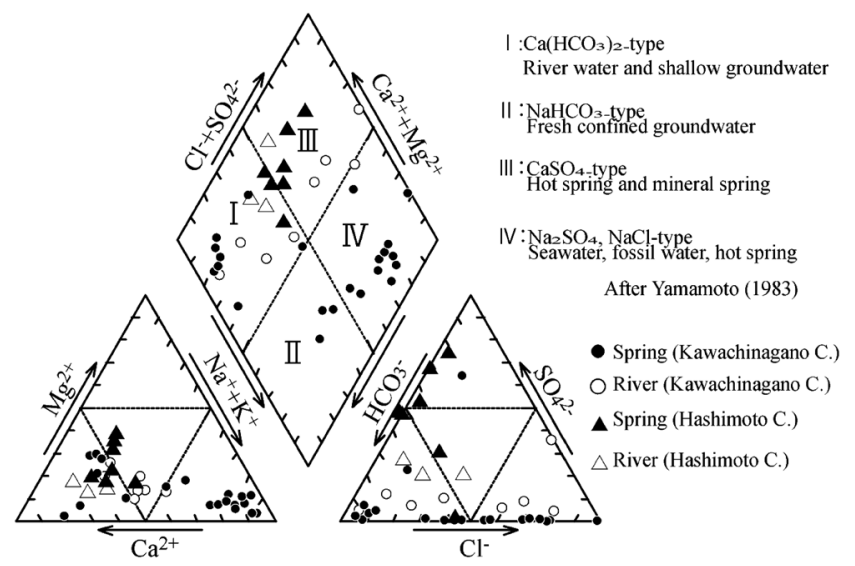

Fig. 8 Trilinear diagram showing the types of groundwater and river water quality. Groundwater quality types are referred to Yamamoto (1983).

する地下水の ECを推定することができ，有馬型 熱水の湧出筒所を面的に捉えることができると考 えられる。河川水の ECは現地において簡易 EC
計により測定した（Fig. 9)。河川に涌水が流入 している箇所では, 部分的に河川水の ECが増加 しており，流下するに従い減少している。Fig. 


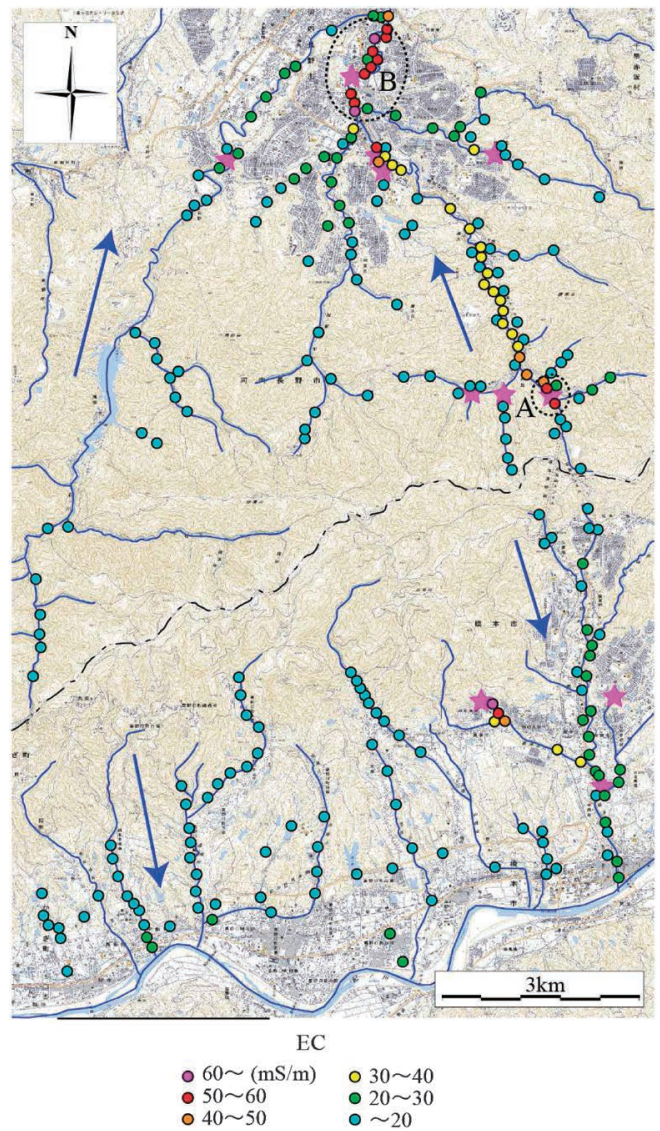

Fig. 9 Distribution of electric conductivity (EC) of river water. Blue arrows show the river flow direction. Stars $(\star)$ show groundwater discharge points. A and B indicate high EC zones.

10 に測定した河川水の EC 值を整理した。測定し た河川水の $\mathrm{EC}$ の平均值は $22 \mathrm{mS} / \mathrm{m}$ であり，一般 的な河川の $\mathrm{EC}$ が数〜 10 数 $\mathrm{mS}$ であることを考慮 すると調查地域の河川水の EC は高い值を示し, 全域にわたって有馬型熱水が混入している可能性 がある。EC值の分布より $40 \mathrm{mS} / \mathrm{m}$ を超える河川 水は，近傍に打いて湧出する有馬型熱水の混入の 影響を強くうけていることが示唆される。このよ うな高 $\mathrm{EC}$ 箇所は，広がりをもって分布しておら ず，スポットとして湧出していることが明らかと なった（Fig. 10; A, B)。さらに尾根部では認め られず，支沢の出口においても高い EC は観測さ れていない。また，地質構造との関係から，湧出

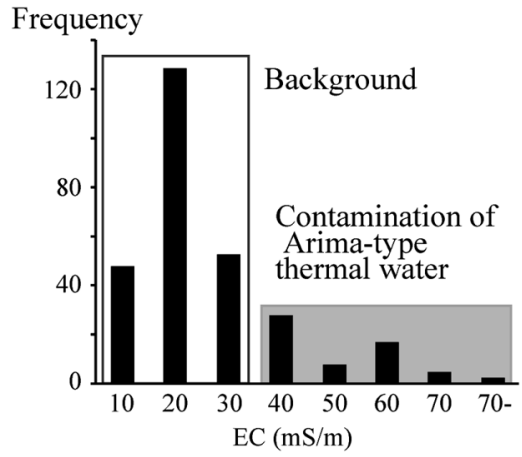

Fig. 10 Frequency distribution of river water EC shown in Fig. 9.

点の多くはMTLおよび派生する東西方向の断層 に沿って分布している。以上より有馬型熱水は河 床や谷底において，断層と河川が交差する場所に 打いてスポット的に湧出していると考えられる。

\section{3 酸素水素安定同位体}

デルタダイアグラムによると, ほとんどの試料 が天水線付近にプロットされる（Fig. 11）。一部 の地下水は酸素同位体比が天水線より重い方にシ フトしており，有馬型熱水端成分と天水との混合 線上にプロットされ，有馬型熱水と天水との混合 により形成されたものと考えられる。調査地域の 有馬型熱水は天水線近傍にプロットされることか ら天水による希釈の影響が大きいものと考えられ る。

\section{V. 考察}

\section{MTL沿いにおける有馬型熱水の上昇・湧出}

紀伊半島 MTL沿いに涌出する地下水は，その 地化学特性より, 沈み込むスラブから放出された 流体である可能性が指摘されている。ここでは, スラブの沈み込みと同時に地下にもたらされた流 体が，脱水過程を経た後に上昇し，地殼において MTLに遭遇し上昇を始めたことを前提として， その後どのような経路により地表にもたらされた かについて考察する。 
田中・東田・村上

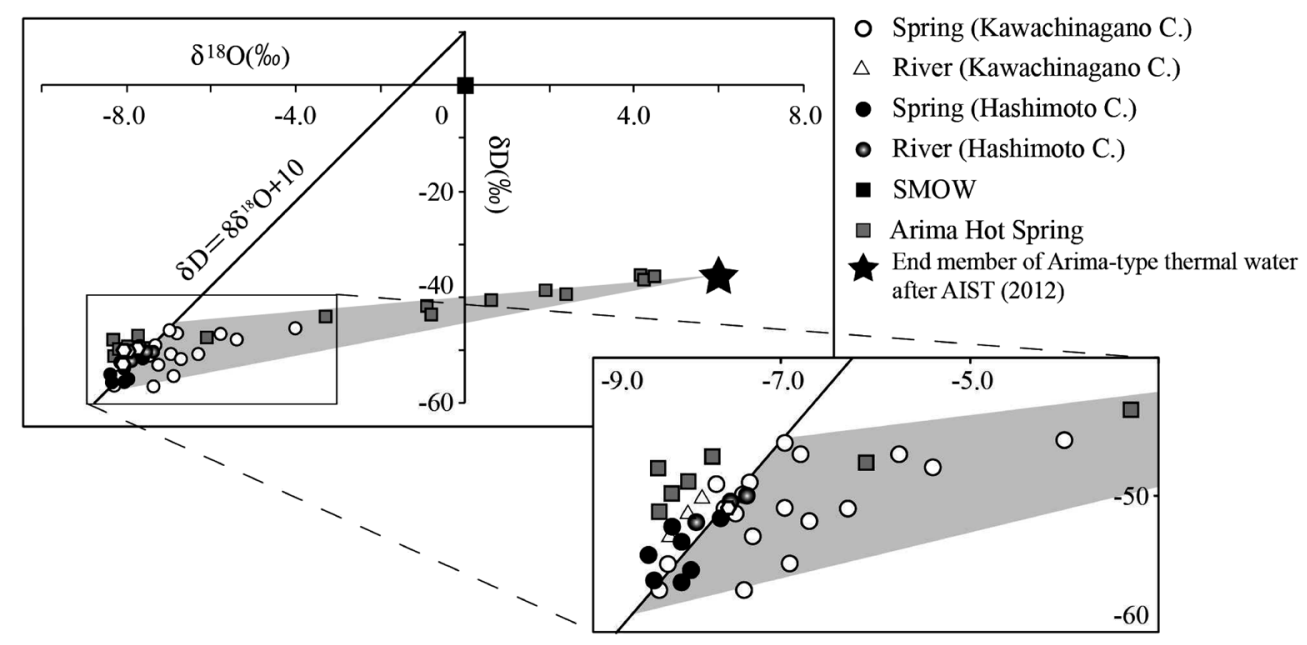

Fig. 11 Delta diagram of $\delta^{18} \mathrm{O}$ and $\delta \mathrm{D}$ of groundwater and river water. The solid line $\left(\delta \mathrm{D}=8 \delta^{18} \mathrm{O}+10\right)$ represents the meteoric line (Craig, 1961). End member of the Arima-type fluid is given from AIST (2012). Data on the Arima hot spring are from Matsubaya et al. (1974).

\section{1. スラブ脱水流体の上昇}

マントル内での上昇プロセスについては不明だ が，超臨界流体として移動し，マントル起源ガス を溶かし込んだ後，地殼にもたらされたものと想 定される (風早ほか，印刷中)。高温高圧の延性 領域である下部地殼に扔いて, どのような経路を 通り上部地凯へ流体が移動するかは現状不明であ るが，広角反射法地震波探查などにより明らかと なった地殼構造（Ito et al., 2009）などにより， 上昇した流体はMTLに沿って上昇を継続し，一 部はMTLの上盤側に発達する RFに分岐し，上 昇すると考えられる。高塩濃度の流体が分岐した RF沿いに上昇した後に，南部の MTLを上昇す ることにより, 有馬型熱水のフラックスは減少 し, 希釈率が高くなるため, 調査地域の北部では 高塩濃度の $\mathrm{NaCl}$ 型および $\mathrm{NaCl}-\mathrm{HCO}_{3}$ 型地下水 が，南部では $\mathrm{CaSO}_{4}$ 型と $\mathrm{Ca}\left(\mathrm{HCO}_{3}\right)_{2}$ 型地下水が 涌出したものと考えられる。南部においても一部 で $\mathrm{Cl}^{-}$濃度の高い湧水が認められており, 一般 に, 岩石中の $\mathrm{Cl}$ 含有量は少なく地下水中の溶存 量も少ないことから (山本, 1983), 南部におい ても天水起源の地下水による希釈率は大きいもの の深部流体の混入した地下水が地表部へ達してい る可能性がある。本調查で確認できた流体の湧出
の認められる断層の分布範囲はMTLの周辺南北 約 $15 \mathrm{~km}$ 区間である。

\section{2. 地表付近における流体の浸透・湧出}

地表に打ける湧出箇所は河床部に限られてい る。これは，尾根部に打ける地下水は鉛直下向き の流動が卓越するために，上昇してきた有馬型熱 水は地表付近では上昇するための駆動力が衰えて おり, 尾根部では地表に湧出できず, 河川や谷部 では被圧に伴う地表への流動が卓越するため, 河 川や谷部に打いてのみ地下水流動に押し上げられ る形で湧出していると考えられる (Toth, 1963)。 流体は脆性領域にもたらされた後，MTLを 通って上昇し, 天水による希釈を受け, 主に断層 破砕帯を上昇し地表へ涌出するが, 断層活動に伴 い形成されたカタクレーサイトや周辺に発達する 網目状に発達する割れ目など透水性の高い䇢所も 通路として流動すると考えられる。さらに, 顕微 鏡スケールの微少割れ目にも深部流体の浸透が起 こったものと考えられる。流体はこれらの間隙に 方解石の脈を沈殿させ，充填鉱物により閉塞した 箇所は通路としての役割をなくし，新たな割れ目 へと涌出の場を移動させたものと考えられる。

以上を整理し作成したMTL沿いに上昇する有 


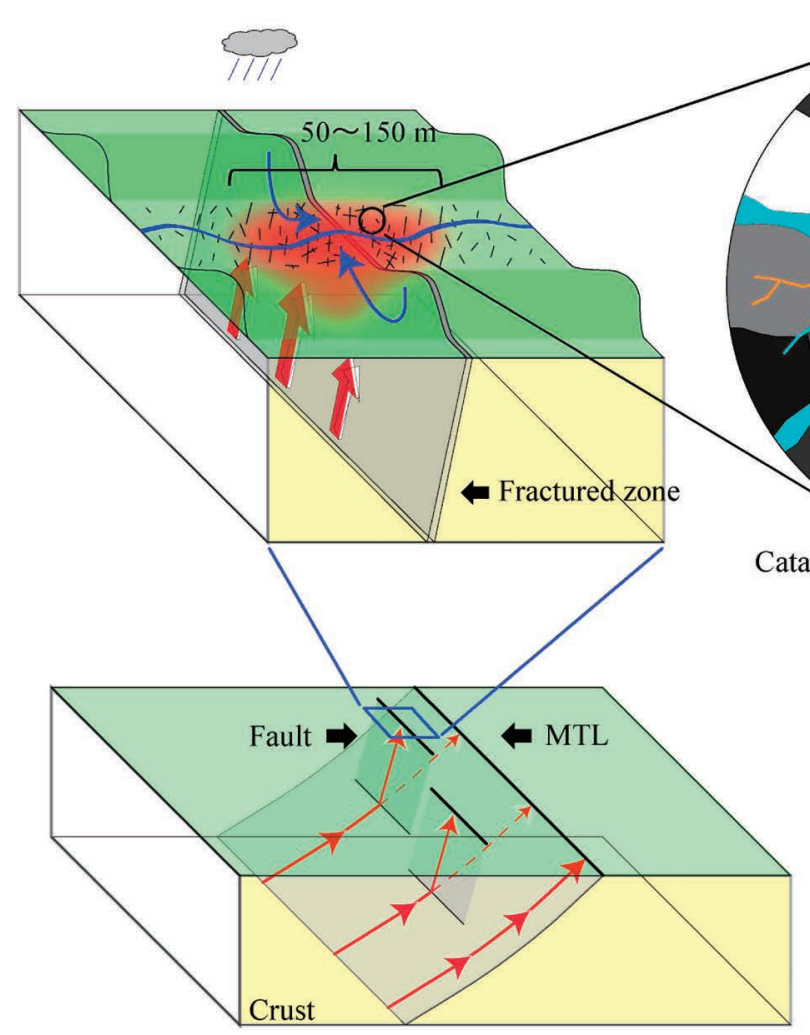

Fig. 12 Upwelling and spouting model of Arima-type fluid in the upper crust. Red lines show the flow paths of the Arima-type fluid, and blue lines show the shallow groundwater flow. Arima-type fluid ascends through the MTL and related faults and penetrates into cataclasites and microfractures.

馬型熱水の上昇，湧出モデルを Fig. 12 に示す。

\section{VI. まとめ}

紀伊半島のMTL沿いにおける有馬型熱水の涌 出する場を規制する要因を検討することを目的と して，地表地質調查打よび地下水の地化学調査を 行い，有馬型熱水の分布域と地化学特性を明らか にするとともに，有馬型熱水の上昇過程や流動形 態について考察を行い，以下の結論を得た。

\section{1. 有馬型熱水の分布と地化学特性}

調査地域北部に湧出する地下水は, $\mathrm{NaCl}$ 型扔 よび $\mathrm{Ca}\left(\mathrm{HCO}_{3}\right)_{2}$ 型の水質を示し, 高 ${ }^{3} \mathrm{He} /{ }^{4} \mathrm{He}$ を 示すガスを伴う（東田・田中，2009）。一方，南 部に湧出する地下水は, $\mathrm{CaSO}_{4}$ 型と $\mathrm{Ca}\left(\mathrm{HCO}_{3}\right)_{2}$ 型地下水が大部分であるが，一部に $\mathrm{Cl}^{-}$濃度の高
いものがあり，天水による希釈率は非常に高い が，有馬型熱水が上昇し混入している可能性があ る。

\section{2. 有馬型熱水の上昇過程}

沈み込むスラブより脱水した流体は，MTLも しくはMTLの上盤側に発達するRFを通路とし て上昇する。その後，地表付近では上昇する駆動 力が衰えており, 尾根部では地表に湧出できず, 河川や谷部において被圧された局地的地下水流動 系に伴い天水による希釈を受け，断層破砕帯や周 辺に発達する網目状の割れ目などの透水性の高い 箇所を通って地表に涌出すると考えられる。

\section{3. 有馬型熱水の湧出を規制する要因}

紀伊半島のMTL周辺における有馬型熱水の涌 出する場は，MTLの分布に規制され，MTLを含 
む南北約 $15 \mathrm{~km}$ 区間が影響範囲と考えられる。 また，数 $\mathrm{km}$ スケールにおいても涌出の場は小規 模な断層に規制されるが，浅層地下水流動にも規 制されるため，断層と河川が交差する場所におい てスポット的に分布する。さらに, 露頭スケール においては，割机目密度，方向，形状，充填鉱物 の有無などによる透水性の違いが湧出を規制し, 顕微鏡スケールにおいては, 割れ目周辺の微小割 れ目にも浸透する。

\section{謝 辞}

本論文の作成にあたり, 熊本大学大学院自然科 学研究科嶋田純教授には酸素水素同位体分析装置 の使用を快く許可して頂くとともに, 有益な助言 をいただいた。山口県産業技術センターの有村一 雄氏には一般水質分析においてご指導いただい た。産業技術総合研究所地質情報研究部門深部流 体研究グループの風早康平博士, 安原正也博士を はじめ同グループの方々には有馬型熱水に関して 有益なご助言・ご指摘を頂いた。2名の匿名査読 者の指摘により論文が大きく改善された。以上の 方々に対して，感謝の意を表します。

\section{参考文献}

岡田篤正・寒川 旭（1978）：和泉山脈南麓域に 打ける中央構造線の断層変位地形と断層運動. 地理学評論, 51, 385-405.

風早康平・高橋正明- 安原正也 - 西尾嘉朗 - 稲村 明彦・森川徳敏・佐藤 努・高橋 浩 $\cdot$ 大沢信 二. 尾山洋一. 大和田道子 $\cdot$ 塚本 斉 $\cdot$ 堀口桂 香・戸崎裕貴 ·切田 司 (2013) : 西南日本に おけるスラブ起源深部流体の分布と特徵. 日本 水文科学会誌，44，1 (印刷中).

核燃料サイクル開発機構（1999）：わが国におけ る高レベル放射性廃棄物地層処分の技術的信頼 性一地層処分研究開発第 2 次取りまとめ一. 総 論レポート, $632 p$.

金折裕司 · 矢入憲二 ·宮腰勝義 (1988)：跡津川
断層北東部における花崗岩類の微小変形構造と その形成過程. 地質学雑誌，94，887-901.

狩野彰宏（1997）: 淡水成炭酸塩トゥファの特徵 と成因：レビュー。地球科学，51，177-187. 小林貞一 (1951)：日本地方地質誌「総論一日本 の起源と佐川輪廻一」. 朝倉書店, 353p.

寒川 旭・岡田篤正 (1977) : 紀伊半島西部の中 央構造線の新期活動に関する断層露頭につい て. MTL, no. 2, 51-60.

産業技術総合研究所深部地質環境研究センター （2007）：概要調查の調査・評価項目に関する 技術資料一長期変動と地質環境の科学的知見と 調査の進め方一. 地質調查総合センター研究資 料集, no. 459, 191p.

産業技術総合研究所地質調查総合センター (2010)：20万分の1日本シームレス地質図 データベース, 産業技術総合研究所研究情報公 開データベース, DB084.

深部地質環境研究コア編 (2012)：概要調査の調 査・評価項目に関する技術資料一立地要件への 適合性とその根拠となる調査結果の妥当性一. 地質調查総合センター研究資料集, no. 560, 産業技術総合研究所地質調査総合センター.

辻村真貴・田中 正（1996）：環境同位体を用い た降雨流出の研究. 恩田裕一 - 奥西一夫 - 飯田 智之 ·辻村真貴編, 水文地形学, 古今書院, 79-87.

中沢圭二・市川浩一郎・市原 実 (1987) : 日本 の地質 6 , 近畿地方. 日本の地質「近畿地方」 編集委員会編，共立出版，297p.

東田優記 - 田中和広 (2009) : 大阪府河内長野市 に打ける $\mathrm{NaCl}$ 型地下水の研究. 平成 21 年度 日本応用地質学会研究発表会講演要旨集, 159-160.

松葉谷治 - 酒井 均 - 鶴巻道二 (1974) : 有馬地 域の温泉, 鉱泉の水素と酸素の同位体比につい て. 岡山大学温泉研究所報告, 43, 15-28.

水野清秀·寒川 旭 - 佃 栄吉 (1994) : 中央構 造線活断層系 (近畿地域) ストリップマップ. 地質調査所. 
山本荘毅（1983）：新版地下水調査法. 古今書 院, 490p.

Craig, H. (1961): Isotopic variations in meteoric waters. Science, 133, 1702-1703.

Ito, T., Kojima, Y., Kodaira, S., Sato, H., Kaneda, Y., Iwasaki, T., Kurashimo, E., Tsumura, N., Fujiwara, N., Miyauchi, T., Hirata, N., Harder, S., Miller, K., Murata, A., Yamakita, S., Onishi, M., Abe, S., Sato, T. and Ikawa, T. (2009): Crustal structure of southwest Japan, revealed by the integrated seismic experiment Southwest Japan 2002. Tectonophysics, 472, 124-134.

Matsumoto, T., Kawabata, T., Matsuda, J., Yamamoto, K. and Mimura, K. (2003): ${ }^{3} \mathrm{He} /{ }^{4} \mathrm{He}$ ratios in well gases in the Kinki district, SW Japan surface appearance of slab-derived fluids in non-volcanic area in Kii Peninsula. Earth and Planetary Science Letters, 216,
221-230.

Toth, J. (1963): A theoretical analysis of groundwater flow in small drainage basins. Journal of Geophysical Research, 68, 47954812.

Umeda, K., Ogawa, Y., Asamori, K. and Oikawa, T. (2006) : Aqueous fluids derived from a subducting slab: Observed high ${ }^{3} \mathrm{He}$ emanation and conductive anomaly in a non-volcanic region, Kii Peninsula southwest Japan. Journal of Volcanology and Geothermal Research, 149, 47-61.

(原稿受付 : 2013 年 4 月 11 日)

(原稿受理 : 2013 年 8 月 2 日)

この論文に対する「討論」を 2014 年 5 月 31 日 まで受け付けます。 


\title{
紀伊半島の中央構造線付近に見られる 深部流体と地質・地質構造
}

\section{田中 和広・東田 優記 $\cdot$ 村上 裕晃}

\begin{abstract}
要旨
紀伊半島の中央構造線近傍に湧出する流体は水質，酸素水素同位体比，ヘリウ ム同位体比などにより，スラブ起源と考えられる有馬型熱水が混入していること が想定される。本研究では地下水や河川水の地化学特性の検討を行うとともに, 露頭に打ける地質学的観察結果にもとづき，流体の上昇経路の検討を行った。流 体は幅 $15 \mathrm{~km}$ 以内に分布するMTL およびそれに平行な分岐断層に伴われる断層 破砕帯に沿って上昇する。その結果，北部の分岐断層からは主に高塩濃度の $\mathrm{NaCl}$ 型および $\mathrm{Ca}\left(\mathrm{HCO}_{3}\right)_{2}$ 型地下水が，南部の $\mathrm{MTL}$ から一部に $\mathrm{Cl}^{-}$の溶存量 の高い地下水を含む $\mathrm{CaSO}_{4}$ 型と $\mathrm{Ca}\left(\mathrm{HCO}_{3}\right)_{2}$ 型地下水が湧出する。

流体は，被圧された局所地下水流動系による希橎を受け，河川と断層の交差す る箇所で局地的に湧出している。断層破砕帯中のカタクレーサイトや微小割机目 は方解石脈に充填されており，流体は断層破砕帯を上昇する際に，これらにも浸 透し，炭酸カルシウムを沈殿させたものと考えられ，その結果，上昇経路は閉塞 され，流出筒所の移動を引き起こしたものと考えられる。

キーワード : 中央構造線, 高塩濃度地下水, 地質構造, スラブ起源水
\end{abstract}

